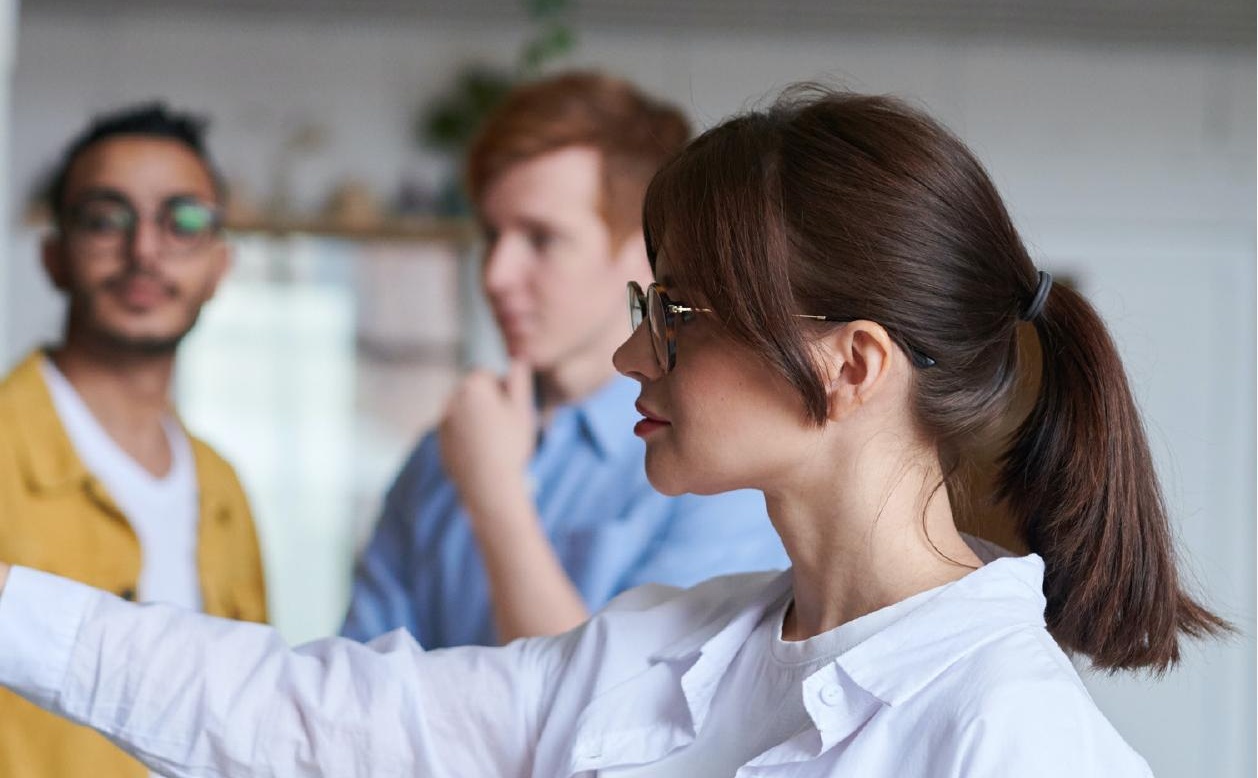




\title{
THE CLASS OBSERVERS AND THEIR SUBJECT POSITION IN THE ELT FIELD
}

\section{Los observadores de clase y su posición en el campo de la enseñanza del inglés}

\author{
Miguel Martínez Luengas ${ }^{1}$ \\ ${ }^{1}$ Universidad Distrital \\ Email: 1'mmartinezl@correo.udistrital.edu.co
}

(Recibido el 05 de mayo de 2021 - Aceptado el 26 de mayo de 2021)

\section{Resumen}

Las observaciones de clase son prácticas constantes llevadas a cabo en el campo del ELT (Enseñanza del idioma inglés). Cuando una persona comienza a estudiar para ser profesor de inglés, esta persona observa los contextos escolares, observa los profesores en los colegios / universidades y también esa persona es observada por el profesor y / o coordinadores. De la misma manera, la observación se utiliza para evaluar los procesos pedagógicos / académicos, se utiliza para retroalimentar, para recoger información en procesos de investigación, entre otros. Sin embargo, hay algunas preguntas relevantes sobre este tema, por ejemplo, ¿quién está observando las clases? ¿Para qué se observa? ¿Existen diferentes posiciones del observador?

Este artículo pretende indagar sobre los aspectos desconocidos detrás de las observaciones de clases de inglés y principalmente, explorar las posiciones de los observadores (sujetos que circulan en esta práctica). Estas posiciones están en constante movimiento y poseen voces, emociones, luchas, deseos y más características dentro de los observadores de la clase en el campo del ELT. El propósito de este texto tiene que ver con la aparición de las diversas posiciones del sujeto observador en el campo del ELT.

Palabras claves: observador de clases, sujeto observador, posición del sujeto, observaciones de clases.

\footnotetext{
Abstract

The class observations are constant practices that are carried out in the ELT (English Language Teaching) field. When a person started studying to be an English Teacher, this person observes the school contexts, the teachers at schools/universities and is also observed by the Main Teacher and/or coordinators. In the same way, the observation
} 
is using to evaluate pedagogical/academic processes, it is done to provide feedback, to recollect data in research procedures, among other ones. However, there are some questions which are important to state about this topic, for example, who is observing classes? what is it observed for? are there different positions of the observer?

This article pretends to inquire about the unknown aspects behind the English classes' observations and mainly, exploring the positions of the observers (subjects who are landed on this practice). These positions are in constant movement and hold voices, emotions, struggles, desires, and more characteristics inside the class observers in the ELT field. The purpose of this text deals with emerging the diverse observer subject position (s) in the ELT field.

Key Words: class' observer, subject observer, subject position, class observations.

\section{INTRODUCTION}

As an observer, I remember an experience in a Public School in Bogotá, Colombia. It was the second observation I ran into this school, suddenly and an English Language teacher told me: "were you going to observe my class?" I replied, "that is right, I am the observer from the (x Institution) then my job is about observing your class," she said, "alright, I would be the best actress right now and, you could see perfect English class". At his specific moment, I realized the importance of researching and problematizing the class observation practices, the normalization of this practice in the ELT (English Language Teaching) field, and the positions of the observers in Colombia.

The class observation in the ELT (English Language Teaching) is about evaluating teaching processes, giving feedback, offering new/innovative techniques in teaching, controlling the role of teachers inside and outside classes, recollecting information, among other aspects.

As a point of departure, the revision of literature allows us to recall Merç's (2015) definition of classroom observation as an operative device of learning on how instructional methods are implemented, how teaching spaces are structured, and how learners react to the classroom setting (p. 194). This comprehension theoretically speaking is related to the ideals that observation practice must be systematic to avoid obtaining a distorted view of what happens in class and that its benefits are tangible: "It needs to be followed through properly, not something is done once and leading nowhere" (Lasagabaster and Sierra, 2011. p. 459). 
Classroom observation has been identified as a relevant device for educational supervision (Hismanoglu \& Hismanoglu, 2010), a component of a staff appraisal mechanism (Lam, 2001), and a tool for self-monitoring (Wichadee, 2011). The observation could be an easy method that teachers can include in their classrooms as they would likely face countless matters (or issues) in the classrooms. This observation also offers devices for educational testing/supervision.

In the ELT field, the class observation has been a normalized practice; it means, this helps the researchers/scholars to recollect data from their projects, at the same time, this practice is implementing in universities from a pre-service teaching strategy (when the pre-service teacher starts this part of the journey, they should observe classes as well as being observed by the Headteacher), and the class observation is using in the evaluating standards of in-service teachers (when there is an opportunity to be promoted and/or the supervisor, coordinator or leader would like to judge the teachers' performance).

Moreover, many people handle certain instruments and rubrics to follow a Class Observation. These help the observer identify the specific patterns of an English Language class, control the step-by-step observation procedure, and allow the observers to move into a rigid and structural guideline. The class observation rubrics are the maps of the observers in which they need to navigate to pursue a suitable observation.

Seeing the previous passages, the position of the ELT class observer is surrounding all of these; the observer is the one who is immersed in the English Language classes, it is the person who has got training to observe classes in a "correct" way and this person has had experience as English Language teacher, coordinator, supervisor and, also has been in the position of an observed subject. About this, it is appropriate to ask, why is it important to observe a class? What about teachers' opinions against the observation practices? What about observers' feelings? Or what does the observer struggle at the time of observing? In this sense, is the observer an instrument, another object, with a trained eye, which eye? And what for? These situations come into play...They are probably in this reflection about the observers' subject positions.

This article pretends to analyze the different subject positions of ELT Observers when carrying out class observations in Colombia. The purpose is to identify some hidden aspects which are not visible in the class observation in the ELT field. From an introspective view and a multifaceted position, the author would like to bring perspectives on the ELT class observation as well as exploring a few subject positions of the Observers in English Language classes. 


\section{LITERATURE REVIEW}

At first sight, the ELT class observation in Colombia seems like a practice where many subjects (Coordinators, teachers, observers, students, among others) are immersed in one way or another. According to this, it is relevant to state theoretical and/or conceptual frameworks to support the explored literature about the topic of observations (observers' subject positions). This part would overview three categories that were extracted from the review of more than 50 research articles, book chapters, news from local newspapers, and other references about the ELT Class observations and the Observers' subject positions.

\section{OBSERVATION AS A TOP-DOWN PRACTICE}

Observation is a practice that should be done by certain kinds of people. The person who handles the observation knows about the requirements, techniques, guidelines, and structure of the observational strategies and this person should have vast expertise in the field. This subject is molded, trained, and positioned as an "expert" in the functions s/ he performs.

The word expert was found and identified in the Colombian National Program: "Colombia Very Well- 2015-2025", as an example. (in the document provided from Ministerio de Educación, they named the importance to have "experts" to help the ELT Colombian Teachers' community) p.4-7. The task of the expert is to provide the appropriate tools for the success of the project. Also, one of the tasks this expert must do is to observe in-service teachers' classes and giving them feedback, offering possibilities to succeed in the ELT lessons; and providing feedback / evaluating a class' structure. The expert (Class observer) sounds like a trainer who can do many tasks. In Wajnryb's (1992) words: "the task of the trainer is to help trainees understand the various processes involved in the teaching and learning of a language and the complex array of activities that occur in a language classroom". (p. 5)

The class observation is a top-down practice, where an expert is the highest tip and, this person helps, criticizes, and evaluates the performance/behaviors of the observed teachers, though they are removing voices from people who are also involved in this practice. Class observation can be a violent, standardized, and normalized practice in the ELT community.

In an earlier study, Martinez 2021 (forthcoming) has argued that classroom observation is and has been a canonical practice, a series of actions to identify, judge, and/or evaluate performances in the classroom over a long time, particularly in the field of ELT. The use 
of observation assessment rests on the idea of encouraging "good practice" in schools, primarily through rubrics that follow a step-by-step procedure of evaluation. In most cases, this implies, in turn, is a need to observe the teacher and what happens in the classroom. Also, he mentions,

We have normalized rituals for the achievement of a good class, and we have also normalized Class Observations as an effective technique. This technique involves demanding patterns, and the teacher must follow specific rubrics, step by step procedures; this is one of the many normalized facets of the Class Observation practice which I have discussed but they raise many disturbing questions which require a guiding thread from here on. (Martínez, M. 2021, forthcoming)

A strategy of the top-down practice in class observation lies in the use of rubrics. These instruments (rubrics, guidelines, formats) are designed and adjusted according to structured parameters in how to teach English classes "correctly". English teachers, directors, observers, and other participants of the ELT field know that English classes follow a step by step to seek "success". Most ELT class models are proposed from abroad to teach our English classes and the guidelines are carried out and proposed from other parts of the world (overseas).

In Annex 1 can be seen, as an example, the particularities of a class observation format in which components related to controlling and discipline are considered from a top-down practice of class observation. Class strategies, contents, procedures, and objectives are evaluated by an "expert". It is possible to show some dynamics of subjection towards the teacher observed through this rubric as well as an evaluation from above (top-down) in terms of the particularities of the observed class. The observation and supervision are part of a schema in the National Bilingualism Plan, they become the disciplinary technologies that measure the program's success. Behind these technologies, there is a canonical logic that EFL (English as a Foreign Language) teachers must follow. The teachers' compliance is a prerequisite for guarantying the success of the procedures.

\section{THE SUBJECT POSITION OF THE OBSERVER}

Another category presented in this literature review is the positioning theory. Harré defined the theory of positioning as being "...based on the principle that not everyone involved in a social episode has equal access to rights and duties to perform particular kinds of meaningful actions at that moment and with those people...". (2012, p. 193). 
The class observer has their positions and roles which are stood in different contexts and particularities. The positions (in this case, the observers) are dynamic; but also, these positions can shift within social settings (Harré and Moghaddam, 2003a). A person in the position deals with situations in context, places, and actions. Thus, the position theory also thrives on the connection among subjects in a social environment. About this, it is important to highlight what Moghaddam and Harré say: "A position includes rights, duties, and obligations of an individual in any social context". (2003a)

About the aspect of the social context within the subject position, Andreouli (2010) states, "Social representations provide both the meanings related to an object as well as the positions towards that object that are available for people; meanings and positions are the two components of social identities" (Duveen \& Lloyd, 1990), p. 14.3.

The class observers deal with rubrics/guidelines that are sets of rules, statements, understandings, and guidelines that define what is true or real at any given time in the Class Observation (CO). The observer arrives at the institution and generates a superior position towards the teacher who accepts the top-down observations from external eyes; an acceptance that interprets the power as an issue of domination.

One of the authors is Li, who identifies that the observers in many parts of the world tend to exercise top-down authority (2009). A position has to do with situations in which the observed teacher sometimes feels dominated at the time of observation; that is, the position of the observer (her/his body, history, and knowledge) is identified, valued, and respected.

As stated before, the author dug into the literature about the subject position of the observer in Colombia. The development of table 1 was carried out as an exercise in intellectual production during the doctoral studies of the author of this article, in a seminar called Critical Discourse Analysis, on the study of English Class Observation Practices, which is the subject studied during the research project.

The different characteristics of classroom observation practices in Colombia from 2012 to 2019 were researched in national government programs/plans, strategies to strengthen English from external institutions, and archives of some Colombian newspapers including news and stories.

Data collection was carried out based on the local Colombian context, and a large volume of information was not handled, which allowed a simple content analysis technique to identify the beneficial information in this study (Tinto, 2013, p. 146). 


\section{Table 1.}

Observations of English classes in Colombia 2012-2019

\begin{tabular}{|c|c|}
\hline Fuente & Descripción \\
\hline $\begin{array}{c}\text { 1. Plan de bilingüismo } \\
\text { Municipal Mosquera (2012), } \\
\text { Bilingualism Plan in } \\
\text { Mosquera. } \\
\text { Mosquera Lives English } \\
\text { 2012-2021 }\end{array}$ & $\begin{array}{l}\text { According to the Bilingualism Plan, class observation } \\
\text { was defined as a valuable tool for improving teacher } \\
\text { performance, because this practice identifies the } \\
\text { components and provides formative feedback on } \\
\text { teacher performance in the classroom (p.15). } \\
\text { Workshop sessions are organized that would be } \\
\text { accompanied by constant class observation in the } \\
\text { classroom with each of the teachers so that they } \\
\text { receive formative feedback on the practical use of the } \\
\text { topics discussed in the workshops (p.47). }\end{array}$ \\
\hline $\begin{array}{l}\text { 2. Ministerio de Educación } \\
\text { Nacional MEN (2014), } \\
\text { Colombia Very Well - } \\
\text { Programa nacional de inglés } \\
2015-2025 \\
\text { National English Program }\end{array}$ & $\begin{array}{l}\text { One of the strategies of the program is based on the } \\
\text { creation of teaching communities, which allow sharing } \\
\text { teaching experiences, learning from each other, and } \\
\text { developing and disseminating best practices (for } \\
\text { example peer observation, the study of lessons, open } \\
\text { classes, etc.). } \\
\text { One of the objectives of peer observation is mutual } \\
\text { observation so that teachers identify opportunities for } \\
\text { improvement in teaching practice (p.74). }\end{array}$ \\
\hline $\begin{array}{c}\text { 3. Hernández Santamaría } \\
\text { (2016), El Mal Economista. } \\
\text { Blog El Espectador, } \\
\text { Newspaper. iBienvenidos los } \\
\text { cambios! Evaluación integral } \\
\text { a los docentes de nuestro } \\
\text { país. }\end{array}$ & $\begin{array}{l}\text { As a key part of this reference, peer watching allows } \\
\text { viewing, at least in part (not a surprise video or hidden } \\
\text { camera). } \\
\text { "[...] The video must be recorded by the teacher, either } \\
\text { with his resources or with an ICFES cameraman, at } \\
\text { no additional cost. The quality of the self-recording } \\
\text { must be guaranteed, for which the MEN has provided } \\
\text { informative manuals and videos, both for the recording } \\
\text { and to adapt the teaching practice to be evaluated, the } \\
\text { video is evaluated by an external person [...]". }\end{array}$ \\
\hline $\begin{array}{l}\text { 4. MEN (2016), } \\
\text { Colombia bilingüe. } \\
\text { Programa de formadores } \\
\text { nativos extranjeros } \\
\text { Native Foreign Trainers } \\
\text { Program. }\end{array}$ & $\begin{array}{l}\text { According to this strategy, foreign native trainers } \\
\text { (fellows), "support the bilingualism managers in the } \\
\text { process of observing classes during their visits to } \\
\text { schools" (p.67). }\end{array}$ \\
\hline
\end{tabular}


As part of the process of the Teacher Training Schools and Teachers, a "Class Observation Rounds Guide" was stated.

5. British Council-

Secretaría de Educación

Distrital.

Convenio 1550 de 2017

Secretariat of Education.

Bogotá, Colombia

Some objectives of the observations are:

"I. Bringing the masters in training closer to the referents of progress.

II. Recognize that the referents of progress are the constitutive elements of good teaching practice, and around which the feedback of the practice will be made. III. Initiate a culture of classroom observation in Teachers-in-training (MF), as a means of good classroom practice" (p.2).

In the formative diagnostic evaluation (ECDF), a general

6. MEN (2018-2019), Manual reference manual is evidenced in which the quality para auto grabación del of self-recording (self-observation) of educational video de práctica.

Evaluación de carácter diagnóstico formativa (ECDF) Another situation has to do with the fact that the video Manual for self-recording of of the educational practice must be part of the period the practice video. Formative in which the teacher is being evaluated and comply diagnostic evaluation with the provisions contemplated in the regulations (p.5).

"[...] In the ECDF, several Colombian teachers are evaluated to determine if they are promoted or

7. Cabrales ( 7 de junio de relocated in salary. One of the techniques is to record 2019), Las 2 Orillas a video. Based on the writer, he argues the following:

"Las fallas del examen de 'The video is nothing more than a farce, a banal show ascenso docente". whose purpose - it seems - is to provide an income to Web Blog "Las 2 Orillas" ICFES and to certain universities that participate in that process and collect a certain important monetary amount' ".

Source. Own design during the study in the academic seminar Critical Discourse Analysis, Doctorado Interinstitucional en Educación de la Universidad Distrital FJDC, Bogotá, 2019.

This table shows sources of information in which English class observations are the main concern, and it is possible to analyze (highlighted) the vertical/dominant positions and power relations that class observers have at the time of doing this practice. 
The position of the subject (observer) is permeated by social characteristics, which have to do with constructions of identity, recognition, and subjectivity particularities. This article, it is tried to take these aspects into account and analyze them from the observer subject perspective in the ELT field.

\section{THE OBSERVER IN THE CLASS OBSERVATIONS}

The observer's subject position needs a skilled and trained eye to perceive, understand, and benefit from observing the proceedings of learning/teaching. The subject position of the observer is produced by the power of experts. (Foucault, 1982)

These learning/teaching spaces the observer takes part in are implemented through an imported structure. About that, I would like to highlight Jordão (2016). She points out that "the "subjects" have submitted to the colonial structure and accepted imported methods, imported language descriptions, and imported acquisition theories". In this article, it is probably seen the imported classroom observation methods, descriptions, and theories will become evident; also, "the imported observers' subject positions" will probably be seen. (p. 196)

Consequently, it would be appropriate to show the hidden narratives of observers/expert subjects at the time of observing, what they think about Class Observation Practices (COP), their points of view at the time of $\mathrm{CO}$, the $\mathrm{CO}$ training, and how their subject positions have changed through/while working on it. As can be seen, observers are also teachers, men, or women with experience in teaching. They have been observed as well and sometimes even they do not agree with CO practices. Subject Position places people into hierarchies (Foucault, 1991). These hierarchies are around a mechanism of control.

The position of the observer is permeated by a mechanism for the administration, control, and evaluation of populations; that is, the observers have privileges but also, the positions of the observers are ignored. It does not matter if the observer is a teachermale or female; the important thing is to obey the quality item which consists of having a rigid, static, and universal position which makes the (others) subject position invisible.

In respect of the observer in the Class Observations, it is important to state what Bruns, Costa \& Cunha say, that the observer also uses different instruments, rubrics, and techniques that help the individual teacher's abilities (2018). It denotes that the observer manipulates a series of instruments and strategies to be able to carry out a successful CO process. In other words, the observer plays the role of "user" of tools while performing their function inside and outside the ELT classrooms. To conclude this part, it seems 
appropriate to mention the observer is also a human being. The observer has feelings, makes mistakes, evaluates, criticizes, and feels. This last part invites us to reflect on the position of the observer, and epistemic, reflective, collaborative, or other positions. Here the relevant thing is to scrutinize the "other" positions that dwell within the observers in the ELT field.

\section{METHODOLOGY}

This article invites the reader to see an ontological perspective. The ontology explores the existence or non-existence of specific entities and the way they relate to each other if they indeed exist. Ontology refers to me as a researcher, ELT educator, observer, and student. However, it is quite complicated to have an ontological stance in the classroom observations within observers; also, this article is based on beings (observers) that exist, and not on the particular situations obtained from them as a series of certain properties. Based on that, it has tried to discover "the position of the being of my existence" through my understanding, experience, and self-reflection.

These concepts of understanding, experience, and reflection from my being have helped me achieve epistemological and methodological positions, particularly in research processes. To reinforce this idea, I would like to quote; “...on that account, ontological considerations come before epistemological and methodological ones. That is why we must deal with the question about who is known before the one about how it is known..." (Vasilachis, 1992a, p. 52).

This is also qualitative research that has some relevant characteristics which help me to specify my epistemological reflection. About this, Vasilachis said,

Qualitative research comprises different orientations and approaches, various intellectual and disciplinary traditions grounded, often, in different philosophical assumptions. All these different orientations, approaches, and assumptions generate new data-gathering and analysis strategies. This variety of views on what is known, what may be known, how it is known, and on the way, findings are to be transmitted demands an acknowledgment that there is not one legitimate way to conduct qualitative research. (p.7)

The methodological research part also seeks to give great importance to the qualitative research, which displays an interest in people's lives, behavior, and interactions (Strauss \& Corbin, 1990, p. 17), and in trying to appreciate those worlds through such views (Savage, 2006, p. 384). Qualitative research seems to be interested in personal narratives and life stories in social contexts. 
The use of narratives also represents a wide panorama of the observers' voices, feelings, and reflections. Narratives might be the text used within the context of a mode of inquiry in qualitative research (Chase, 2005) (Adapted from Denzin, 1989 b.).

Another purpose in the observers' narratives allows this research to notice ignored and invisible aspects of the CO. The participants of this study are narrators of our own stories and it would be interesting to analyze them so that in the future we could find out hidden subjectivities of the observers, what is not written in the rubrics, and what possibly helps in the field of ELT through the analysis of those stories.

The objective of this biographical/autobiographical study reveals evidence about the feelings, struggles, achievements, and failures, that observers have from their positions. It is possible to identify some sensations with a biographical/autobiographical narrative that are not found in previous research papers.

The methodology of this research focuses on the study of my being as a classroom observer and as a teacher-researcher (this is also another methodological aspect in this article, the autobiographical path. This would offer important challenges but the purpose stands on the social theories that presuppose contrasts between individuals and groups (it is me reflecting about myself and the tensions I go through along this research process). In the autobiographies, it could emerge the authenticity and reflections about my experience as an observer. The "turn to biographical methods" is explained as a reflective contemporary interest in dealing with biography as a way of constructing meaning and authenticity from people's experiences of a rapidly changing modern world. (Bron et al., 2000, p.12)

It is also important to talk about the involved subjects (participants) in this research. Three close colleagues have received training to observe ELT classrooms and have worked as observers for several years in the Ministry of Education / Secretariats of Education in Colombia and worldwide. We also have been working together for more than five years and we know the "territory" of Classroom Observation Practices (COP) in the Colombian ELT community.

It is meaningful to share as observers and be part of education projects in Colombia where the COP was our daily routine, and we had many valuable stories to bring into this research project.

The first observer works in a well-recognized university. She was also part of a team of observers in the Secretariat of Education of Bogotá, Colombia, and has been working in external entities for some years. She is a great academic researcher, a passionate educator 
with a high level of critical thinking, and is a fan of the arts.

Another teammate has been ELT Consultant for over five years here in Colombia. He has carried out many observations in schools, universities and was working most recently with the MEN. He has experience in both international and local education projects. We have shared amazing moments in training, national trips, and COP events. He is a good friend, is kind, is a collaborative person, and has a beautiful dog called Pepita.

Finally, there is another friend who has been working as an ELT consultant, observer and advisor for several years in universities, schools, and institutes in Colombia. He has participated in many classroom observations and was part of the language improvement strategies in the Secretariat of Education of Bogotá, Colombia. We have been friends for a long time and have done research projects together as well as participated in academic events, workshops, and talks, among others.

There are some common aspects such as expertise in COP, professional similarities, working experience, and academic background among this Team in the research. But it is necessary to say that there are some ontological dissimilarities related to the participants (likes, interests, wonders) which are part of this research.

\section{RESULTS}

In this section, the reader will be able to analyze the results of the class observers' subject positions. It is important to establish that the information obtained (data) was collected through interviews, informal conversations, biographical narratives, and stories of the observers who participate in this research project.

The results presented are not definitive, since this research is still ongoing and is a subjective process in which some situations may change, as well as include new narrative passages from the observers. Biographical parts of the observers will be included, stories they have had throughout their role as an observer, and a brief analysis by the writer of this article.

This first text was taken because of a conversation between two observers, talking about the research project and reflecting upon the role/position of an observer of English language classes. The observer has mentioned,

"I think the observation is an institutional cultural practice; by this I mean, it is a cultural practice, but related to a microstructure that is institution-based, rather than a broad 
culture of observation countrywide. I have been both observed and observer, and I guess there is no similar outcome in the observations I have been part of. As an observed teacher, I am expected to comply with the checklists criteria, as well as with institutional expectations set by administrators. As an observer, my main role was to gather information so as to comply with some governmental requirements set by local authorities. The observation as an observed teacher clearly has an impact on my performance plan as an employee. As of the teachers I observed, the exercise was rather anecdotal and descriptive, rather than a job jeopardizing practice. (Conversation 2. June 2020, Bogotá)

The intention is not to provide rigid/structural positions to this text since people can interpret it in different ways. But it is relevant to notice the observer argues that class observation is a cultural practice, perhaps in our field (ELT). At the same time, it is necessary to use the rubrics when the observation practice is carried out, both to evaluate and to provide feedback. Also, it is pointed out about the importance of collecting information through observation, it is a practice that requires special skills and subjects who do it in a good way.

At the same token, there is a biographical excerpt that was written by the author of this article. Ten biographical chapters have helped the author to problematize the positions of the observers as well as identifying subjectivities in the practices of CO.

Unbelievable, this entity " $x$ " did not see the Teachers as great professionals, I was totally in disagreement with this. At this time, I could not explore the practices of Teachers, actually, I did not have enough experience by interacting and talking to them. As I said just before, I thought the Teachers were brilliant in their lessons as well as terrific practitioners with little children.

Well, I traced back to my first day of "in-situ" dates with a Public School as an "expert Observer" (it was 2013). It was an under-pressure activity to generate worried, anger, and desperate actions... the second one about observers is a huge lie!!! I am not the one who must tell a teacher what to do or when to do... more than an observer, I was a deputy of functions, a dictator of knowledge, in other words: an idiot who follows rules and a script. Things have changed a lot recently!!! (Autobiographical Chapter 5 "A nice talk", October 2019)

This second story has to do with a reflective exercise that I have developed during my doctoral studies. I wrote some autobiographical chapters, where I tried to reflect on my experiences, stories, and feelings as an ELT Observer. This chapter shows a reflective, sentimental, and critical observer position towards the practice of $\mathrm{CO}$. It is also possible 
to identify the importance of recognizing the work of teachers (from an observer's eye), how the observer places in the shoes of an observed teacher, and the reactions/thoughts behind this position of the observer.

As the last result of the observers' narrative (in the process of study), a biographical passage of one observer is presented as,

In 2007. The first time I evidenced rigorous/standardized observation as a CELTA trainee. By then I had been teaching for almost 7 years, so you can imagine how new and strange it was to be hardly criticized about my teaching (when I had lived experience of what worked for me, but the 'CELTA method' disagreed). It was then that I decided I wanted to be a teacher trainer and do it better (than my trainers) (Observers' biographical written text, February 2021)

The final section identifies the need to get "rigorous" training to be an observer. To do this, several methods, strategies, rules, and others are using, which show that observation is a structural and demanding process that needs to be carried out by "experts" and/or "trainers".

\section{CONCLUSION / FURTHER COMMENTS}

In this article, I have discussed the tentative subject positions of observers. In turn, a preliminary analysis has been carried out on the stories, experiences, and feelings of the observers. Based on this, the methodological category that will use the researcher is reconstructing the told from the telling (Mishler 1995). I should reorder (reconstruct) a storyline from the telling (s) (Observers' stories). And this reconstructed passage becomes the "narrative for further analysis" p. 95.

To carry out an in-depth analysis, this research proposes a chronological construction of the observers' subject positions. Brunner (1991) mentions that narratives have chronological connections. He argues that one event comes before another event; and narratives deal with a logical connection, it means, one event causes another event.

Based on this, an initial chronological analysis of the observers' subject positions is presented in this timeline.

This timeline is a chronological analysis of the observers' subject positions of one of the four observers immersed in the research. The reader may notice there is a starting point in dates, but there it is not finished, since (mentioned before), this is ongoing research, 
and new reflections or positions may pop up in this study.

\section{Figura 1.}

The class observer and their subject position (s) in the ELT field

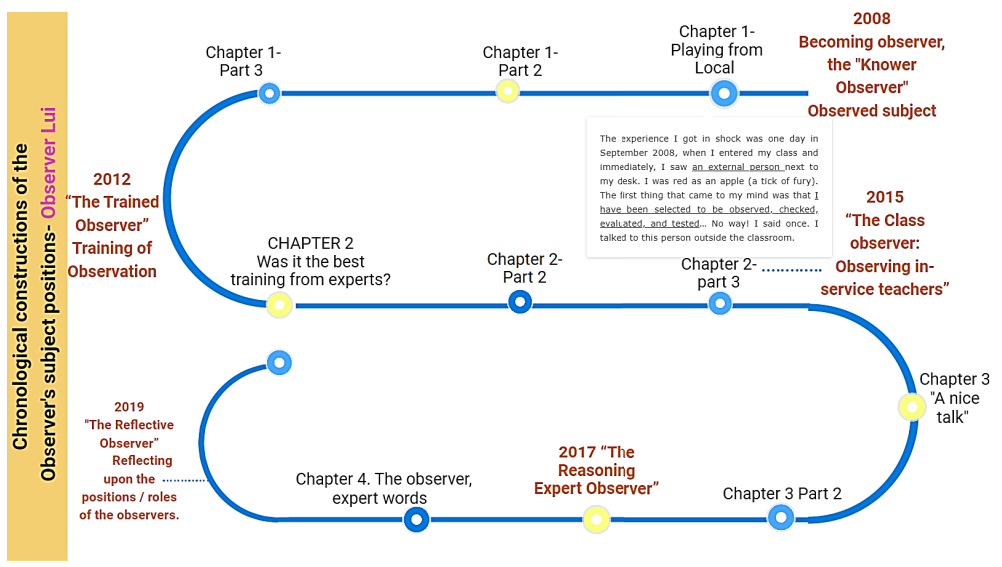

Source. Own design. Slide from the presentation "The class observer and their subject position (s) in the ELT field" in the III National Workshop on Teaching and Learning Foreign Languages, Instituto Internacional de Idiomas de la seccional Sogamoso, UPTC, 2021.

To conclude, it is evident that this observer has started in 2008, there the position is: The knower. There are several events (chapters included) that round this knower position until 2012, where the observer's position is permeated by training and the different observation methods/models. He is named as Trained observer. In 2015, the observer was beginning to observe in-service teachers and knew the dynamics of observation in educational institutions and others. This position is Observing in-service teachers. In 2017, the position of this observer has elements of expertise and vast mastery of practice/ theory, it is recognized as Reasoning Expert Observer. And until 2019 the position of the observer changes, circulates, is in a permanent movement to reach the Reflective observer. As is stated, every position includes different chapters which contain stories, experiences and, voices from the observer as well.

Finally, it is important to mention this article goes into the reflection of the positions of the subjects (observers) who have walked through and living day by day.

It is not easy to evaluate myself, but I think it is necessary to talk about those struggles of the observers, our desires, our stories, how variable our subjectivities are and, how important is to raise the voices and positions of the observers in the ELT field. 


\section{REFERENCES}

Andreouli, E. (2010). Identity, Positioning, and Self-Other Relations. Papers on Social Representations. Volume 19, Peer-Reviewed online journal.

Biesta, G. and Tedder, M. (2007). Agency and learning in the life course: Towards an ecological perspective. Studies in the Education of Adults 39 (2).

British Council-Secretaría de Educación Distrital, Convenio 1550. (2017). Guías para la Ronda de observación de clase. Escuelas Formadoras y Maestros de Maestros EFMMa. Guía de Rondas de Observación de Clase.

Bron, A. and West, L. (2000). Time for stories: The emergence of life history methods in the social sciences. International Journal of Contemporary Sociology 37(2), 158-175.

Bruner, J. (1991). The Narrative Construction of Reality. Critical Inquiry, Vol. 18, No. 1. pp. 1-21 The University of Chicago Press.

Bruns, B; Costa, L; Cunha, N. (2018). Through the Looking Glass: Can Classroom Observation and Coaching Improve Teacher Performance in Brazil? Policy Research Working Paper; No. 8156. World Bank, Washington, DC. World Bank. https://openknowledge.worldbank.org/ handle/10986/27962 License: CC BY 3.0 IGO.

Cabrales, D. (2019). Las fallas del examen de ascenso docente. Las 2 Orillas. https://www. las2orillas.co/las-fallas-del-examen-de-ascenso-docente/

Chase, S. (2005). Narrative inquiry: Multiple lenses, approaches, voices. In N. K. Denzin \& Y. S. Lincoln, The Sage handbook of qualitative research (3rd ed., pp. 651-680). Thousand Oaks, CA: Sage.

Denzin, N. K. (1989b). The research act (3rd ed.). Englewood Cliffs, NJ: Prentice-Hall.

Duveen, G., \& Lloyd, B. (Eds.). (1990). Social representations and the development of knowledge. Cambridge University Press. https://doi.org/10.1017/CBO9780511659874

Foucault, M. (1982). The subject and Power- Critical Inquiry. The University of Chicago Press.

Foucault, M. (1991). Discipline and Punish: The birth of a prison. London, Penguin. 
Harré, R., \& Moghaddam, F. (Eds.). (2003). The self and others: Positioning individuals and groups in personal, political, and cultural contexts. Praeger Publishers/Greenwood Publishing Group.

Harré, R. (2012). Positioning theory: Moral dimensions of social-cultural psychology. In J. Valsiner (Ed.), Oxford library of psychology. The Oxford handbook of culture and psychology (p. 191-206). Oxford University Press.

Hernández, P. (2016). ¡Bienvenidos los cambios! Una evaluación integral a los docentes de nuestro país. El Mal Economista. El Espectador. https://blogs.elespectador.com/ economia/el-mal-economista/bienvenidos-los-cambios-una-evaluacion-integral-a-losdocentes-de-nuestro-pais

Hişmanoğlu, M., \& Hişmanoğlu, S. (2010). English language teachers 'perceptions of educational supervision in relation to their professional development: A case study of Northern Cyprus. Novitas-ROYAL (Research on Youth and Language), 4(1), 16-34.

Jordão, C. M. (2016) Decolonizing identities: English for internationalization in a Brazilian university. Interfaces Brasil/Canadá. Canoas, v. 16, n. 1, 2016, p. 191-209.

Lam, S. F. (2001). Educators' opinions on classroom observation as a practice of staff development and appraisal. Teaching and Teacher Education, 17(2), 161-173.

Lasagabaster, D \& Sierra, J. (2011) Classroom observation: desirable conditions established by teachers. European Journal of Teacher Education, 449-463.

Li, Y.-L. (2009). The perspectives and experiences of Hong Kong preschool teacher mentors: Implications for mentoring. Teacher Development 13: 147-58.

Martinez 2021 (forthcoming). The Observer, the Teacher, and the "Expert"- Unseen situations in Classroom Observation Practices. Capítulo libro, ELT Research Agendas II. Doctorado Interinstitucional en Educación, Universidad Distrital.

Merç, A, (2015). The Potential of General Classroom Observation: Turkish EFL Teachers' Perceptions, Sentiments, and Readiness for Action. Redfame Publishing.

Ministerio de Educación Nacional (MEN). (2014). Programa nacional de inglés- Documento de socialización Colombia Very Well 2015-2025. https://www.mineducacion.gov.co/1759/ articles343837_Programa_Nacional_Ingles.pdf 
Ministerio de Educación Nacional (MEN). (2016). Colombia Bilingüe-Teaching Fellowship Program. https://www.mineducacion.gov.co/1621/articles-132560_recurso_pdf_ programa_nacional_bilinguismo.pdf

Ministerio de Educación Nacional (MEN). (2018-2019). Manual para autograbación del video de práctica. Evaluación de Carácter Diagnóstico Formativa (ECDF). https://www. mineducacion.gov.co/1759/articles-382455_recurso_3.pdf

Mishler, E. G. (1995). Models of narrative analysis: A typology. Journal of Narrative \& Life History, 5(2), 87-123. https://doi.org/10.1075/jnlh.5.2.01mod

Plan de Bilingüismo Municipal Mosquera. (2012). Mosquera Lives English 2012-2021.

Plan de bilingüismo municipal "Mosquera Lives English". Recuperado de: https:// mosqueracundinamarca.micolombiadigital.gov.co/sites/mosqueracundinamarca/ content/files/000155/7716_mosqueralivesenglish.pdf

Savage, J. (2006). Ethnographic evidence: The value of applied ethnography in healthcare. Journal of Research in Nursing, 11(5), 383-393.

Strauss, A. \& Corbin, J. (1990). Basics of qualitative research. Newbury Park, CA: Sage.

Tinto, J. (2013). El análisis de contenido como herramienta de utilidad para la realización de una investigación descriptiva. Un ejemplo de aplicación práctica utilizado para conocer las investigaciones realizadas sobre la imagen de marca de España y el efecto país de origen. Provincia, (29),135-173. https://www.redalyc.org/articulo.oa?id=555/55530465007

Vasilachis, I. (1992a). Métodos cualitativos. Los problemas teórico-epistemológicos. Buenos Aires: Centro Editor de América Latina.

Wajnryb, R. (1992). Classroom Observation Tasks: A Resource Book for Language Teachers and Trainers. Cambridge University Press.

Wichadee, S. (2011). Professional development: A path to success for EFL teachers. Contemporary Issues in Education Research (CIER), 4(5), 13-22. 